\title{
Substantivization of adjectives
}

\author{
Stefan Höfler \\ University of Copenhagen, Copenhagen, Denmark \\ hoefler@hum.ku.dk
}

\begin{abstract}
The process of deriving substantives from adjectives in the classical Indo-European languages can be accomplished in two fundamentally different ways. The first possibility is a derivational one, i.e. the adjective is substantivized by a word-formation process that typically consists of an overt morphological or morphonological operation such as suffixation, accent shift, introduction of new ablaut grades, or a combination thereof. The second process, on the other hand, is a gradual one: an adjective can be substantivized through the ellipsis of a head noun that this adjective was originally paired with. In this paper, I intend to outline the differences and similarities between these two mechanisms and discuss their role in the interpretation of Proto-Indo-European stems in *-(e-) $h_{2}-$.
\end{abstract}

\section{Keywords}

substantivization - nominalization - ellipsis - agreement - adjectives

\section{$1 \quad$ Introduction}

When talking about substantivization (or nominalization) of adjectives, most Indo-Europeanists will probably first think of substantivizing suffixes such as ${ }^{*}-(o) n-,{ }^{*}-(o / e) t-,{ }^{*}-i_{-},{ }^{*}-(e) h_{2^{-}}$, etc., ${ }^{1}$ and formations like Lat. Catō, -ōnis m., a name (literally 'clever one'), from catus 'clever', Gk. $\Sigma \tau \rho \alpha ́ \beta \omega \nu,-\omega \nu \circ \varsigma \mathrm{m}$., a name (literally 'squint-eyed one'), from $\sigma \tau p \alpha \beta o ́ s ~ ' s q u i n t-e y e d$ ', or Goth. blinda m. 'a blind one' (as in Lk 18.39: blinda sums sat faur wig 'a certain blind man sat by

1 For these suffixes see recently Nussbaum (2014: 304-o6). 
the way'), from blinds 'blind', and so on. ${ }^{2}$ Substantivizing suffixes are known in modern languages, too. Compare English $-y$ (as in smart $\rightarrow$ smarty 'knowit-all', or white $\rightarrow$ whitey 'a silvery fish'), German -ling (as in schwach 'weak' $\rightarrow$ Schwächling 'wimp, weakling', weiß 'white' $\rightarrow$ Weißling 'white butterfly'), or French -et (as in rouge 'red' $\rightarrow$ rouget 'red mullet (a fish)', bleu 'blue' $\rightarrow$ bleuet 'cornflower'). These suffixes are, however, quite marginal and largely unproductive. The substantivization of adjectives in languages like English, German, and French is productively achieved by a combination of syntactic, morphological and/or lexical methods: to refer to something that is green we can say a green one or the green one in English, ein Grüner/eine Grüne/ein Grün(es) or der Grüne/die Grüne/das Grün(e) in German, and un vert/une verte or le vert/la verte in French; to refer to the abstract concept of 'green-ness', we can use a/the green, ein/das Grün, and un/le vert, respectively (as in the green of the dress, das Grün des Kleids, le vert de la robe). What can be seen from these examples is that the article ( \pm morphological or lexical material) fulfills the role of a determiner to substantivize an adjective. In functional terms, we could therefore think of the PIE suffixes ${ }^{*}-(o) n-,{ }^{*}-(o / e) t-,{ }^{*}-i-,{ }^{*}-(e) h_{2}-$, etc., as analogous to our modern-day articles, though this anachronistic comparison should not be overstrained.

Yet there is another, lesser-known process that leads to the substantivization of an adjective, both in PIE and the IE daughter languages. This process is ellipsis, and it is - as we shall see-fundamentally different from the mechanisms outlined above. An ellipsis is the omission of a substantive that an adjective was originally paired with, so that the adjective alone remains in substantivized meaning. A case in point is the Latin adjective calidus 'hot' in the syntagma aqua calida 'hot water' (Cato Agr. 156.5 [brassicam] coicito in aquam calidam 'throw [the cabbage] into hot water') and (with ellipsis of aqua) in the substantivization calida f. 'hot water' (Cato Agr. 156.3 qui poturus erit, lauet calida 'before drinking from it, one should bathe in hot water'). In this paper, I intend to outline and discuss the basic similarities, but also the fundamental differences between these two descriptive types of substantivization of adjectives.

2 See, for example, Weiss (2020: 329). 


\section{$2 \quad$ Ellipsis}

Substantivization via ellipsis ${ }^{3}$ is a gradual process. It starts out as a syntactic phenomenon, and at this stage is known as contextual ellipsis or antecedentbased ellipsis (cf. Günther 2018: 77-78 with references). An example from Ancient Greek with the adjective xúvelos 'belonging to a dog' can be seen in the following passage from (Archigenes apud) Galen Comp. Med. Sec. Loc. 6 (12.954).

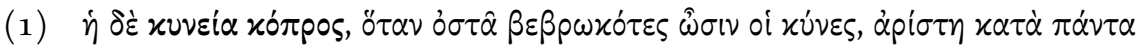

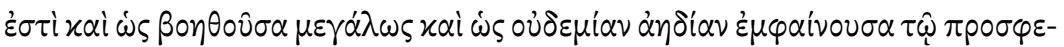

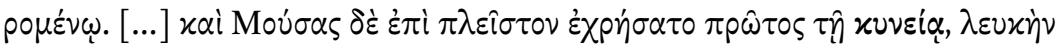
$\dot{\alpha} \varepsilon \grave{i} \pi \alpha \rho \alpha \lambda \alpha \mu \beta \dot{\alpha} \nu \omega \nu$.

'Canine excrement of dogs which were fed bones is by far the best and helps a great deal, and furthermore causes no nauseousness to the patient. (...) Musa was the first one to use canine (sc. excrement), he always took the white one.'

Since a xuvei $\alpha$ xó $\pi$ pos is mentioned at the beginning of the passage, the context allows the substantive xó $\pi$ pos 'excrement' to be ellipted in the second reference ( $\tau \hat{\eta}$ xvveí $\alpha$ ) without this being detrimental to the overall comprehensibility of the sentence. Note that the adjective $\lambda \varepsilon v x \eta \eta v$ in the clause immediately following $\tau \hat{\eta}$ xuvsía is likewise a case of ellipsis, yet an even more subtle one since the antecedent is again the noun xómpos (or, conceivably, xvveí $\alpha$ ), but without there being an earlier reference to a syntagma $\lambda \varepsilon u x \dot{\eta}$ xó $\pi$ pos (or, for that matter, $\lambda \varepsilon v x \dot{~} x \cup v \varepsilon i \alpha$ ). In both cases, the context provides the pragmatic background that enables our understanding of the passage. If the context is, however, ambiguous, the omission of the word xómpos would not lead to a meaningful sentence.

The same can be said about an example from Modern English. Billy Joel's 1977 song Scenes from an Italian Restaurant concludes after almost 8 minutes with the following verses: A bottle of red, a bottle of white / Whatever kind of mood you're in tonight / I'll meet you any time you want / In our Italian Restaurant. Any listener immediately understands that the singer refers to a bottle of red or white wine that he offers to drink with the object of his desire even

3 Ellipses are discussed, e.g., by Fraenkel (1910-12 II: 136-38); Wackernagel (1920-24 II: 53); Panagl (1989: 188-89); Schaffner (2001: 328). 
though the word wine is never explicitly uttered in the entire song-it is just not very likely that someone would like to drink red or white dye, red or white pasta sauce, and perhaps not even red or white non-alcoholic grapejuice. Without context, however, sentences like Here is a bargain organic white or I'd have preferred red are not immediately understandable as referring to white wine or red wine, respectively. Compare the same sentences, but with antecedent: Languedoc is better known for its red wine, but here is a bargain organic white from Château de Lascaux and He gave me a glass of white wine but I'd have preferred red. ${ }^{4} \mathrm{Just}$ for the sake of the argument, however, the sentences, in a different context, could also read: Our company is better known for red pasta sauces, but here is a bargain organic white (one) with bacon and gorgonzola and He gave me a glass of white grape juice but I'd have preferred red.

Only over the course of time has such a contextual ellipsis the potential to become visible and relevant as an actual and descriptive word-formation process. ${ }^{5}$ The final step of this development is the lexicalization of the adjective as a substantive. Whether or not the process reaches this point (and the majority of contextual ellipses do not) is undoubtedly facilitated by a gradual obsolescence of the adjective in adjectival meaning in other contexts than with the soon-to-be ellipted substantive (which is arguably the reason why red and white cannot be interpreted as lexicalized substantivizations in the meaning 'red wine' or 'white wine'). ${ }^{6} \mathrm{~A}$ telling example comes from Vedic, where we find a substantivization Ved. mahișá- $\mathrm{m}$. 'buffalo' $(R V+)$. The underlying adjective mahișá- started out as an ordinary adjective meaning 'tremendous' (from * $m e g h_{2}-s-o_{-}$- 'having (considerable) size'), but already in the Rigveda is only marginally used to refer to things other than the buffalo, as in 10.66.10 mahișásya tanyatós 'of tremendous thunder'. In the other adjectival attestations it is used in combination with mrgá- m. 'animal', denoting 'the tremendous animal' (for example mahișám mrgám RV 8.69.15), i.e. the 'buffalo', which explains the lexicalization of mahișá- in its substantivized meaning. The sub-

4 For the latter example cf. Huddleston (1988: 35; slightly modified). The former example is taken from https://www.thewineandcheesecask.com/newsletter_archive/2019/newsletter Janig.html (last access 28 July 2020).

5 For some typological remarks on the diachrony of ellipsis-like constructions see Valera (2015: $3^{2} 5^{-26)}$.

6 Compare the English word genitive, originating via ellipsis from genitive case, with the adjective genitive nowadays being very restricted in usage. See $O E D$ (s.v. genitive, adj. and n.) where examples for an adjectival usage of genitive in the sense ' $[\mathrm{r}$ ] lating to reproduction or the generation of offspring. rare after 17th cent.' (meaning A.2.) include a 1918 quote by J.H. Kellogg: 'The increased consumption of meat was the potent cause of the failure in the genitive power of the British race.' 
stantive mahișá-, unlike the adjective mahișá-, lives on in the Modern Indic languages (cf. Konkani mhos 'buffalo'). ${ }^{7}$

Cases of Greek ellipses on their way to become fully lexicalized before our eyes include $\dot{\eta} \delta \varepsilon \xi \dot{\alpha} / \delta \varepsilon \xi ı \varepsilon \rho \dot{\alpha}$ (with or without $\chi \varepsilon i \rho$ ) 'the right hand' (in Homer already always without $\chi \varepsilon \dot{i}$ ), $\dot{\eta} \gamma \nu \mu \nu \alpha \sigma \tau i x \dot{\eta}$ (with or without $\tau \dot{\varepsilon} \chi \nu \eta)$ 'gymnastics',

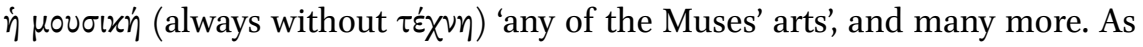
can be seen from all these examples, the gender of the substantivized adjective depends on the gender of the ellipted word. ${ }^{8}$

Examples with textual evidence for the adjective, the syntagma of adjective and substantive, and the substantivized adjective — as with Ved. mahișá'tremendous', mahisáá- mrgá- 'tremendous animal', and mahisáa- m. 'buffalo', or similarly Ved. prthvit- 'broad' (the feminine of prthú-), kșấm ... prthvím 'broad

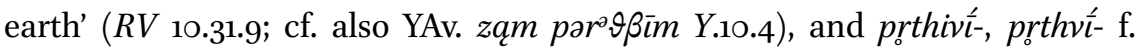
'(Mother) E/earth' - are actually not too common. In many cases we are not lucky enough to have actual evidence from texts that authorize a secure interpretation as an ellipsis. In some cases, the adjective is attested but the underlying syntagma is not, as in Gk. $\psi \omega \lambda$ ó $^{\prime}$ 'with the foreskin drawn back' and $\psi \omega \lambda \dot{n}$ f. 'membrum virile praeputio retracto' (Ar.), which is from an unattested * $\psi \omega \lambda \dot{\eta}$ $\pi \delta \sigma \theta \eta$ with $\pi \delta$ ó$\theta \eta$ f. 'penis', and in yet other instances, not even the adjective is attested. Compare (V)Lat. "formaticus 'shaped', the source of French fromage, Italian formaggio, Catalan formatge 'cheese', where the underlying unattested syntagma is *caseus formaticus 'shaped cheese' (as opposed to unshaped fresh cheese), containing an otherwise unknown adjective *formāticus 'shaped' (derived from forma 'form, mold' like umbrāticus 'belonging to the shade' from umbra 'shadow, shade' and viāticus 'pertaining to traveling' from via 'road'),

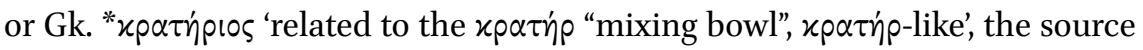
of xpatnpia f. 'bowl' (Dsc.), which is from an unattested syntagma * $x p \alpha \tau \eta$ -

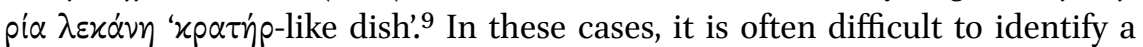
substantivized adjective as an ellipsis-based substantivization. But since an ellipsis-sourced substantivization is morphologically still just an adjective, it is conceivable that the substantivization process did not have any 'morphological effect' (i.e. no suffixation, no accent shift, no change in ablaut ${ }^{10}$ ), which

7 Cf. EWAia (II: 340 s.v. mahisáá-).

8 Compare also Lat. caprea, -ae f., the generic term for 'roe-deer', whose feminine gender is explained very elegantly by Adams (1985b: 278$)$ as originating in a syntagma of the old

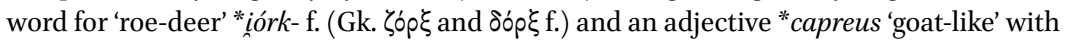
subsequent ellipsis.

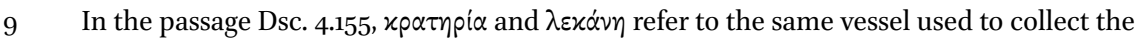
juice of some sort of wild cucumber.

The term 'effect' is used here in purely descriptive terms. In connection with accent shift 
separates them from substantivizations that are created by means of the substantivizing suffixes mentioned above.

\section{3 'Direct' substantivization}

In order to draw a clear distinction between the two types of substantivizations, I intend to name the non-ellipsis type 'direct' substantivization, in the sense that the adjective is converted 'directly' into a substantive without the prior existence of a syntagma of substantive plus adjective and subsequent ellipsis. Unlike ellipsis that evolves gradually, a 'direct' substantivization is a spontaneous and deliberate word formation process, which is especially clear in the many cases where suffixation or another 'morphological effect' is involved (on which more below). The result of this process ${ }^{11}$ can be either:

(A) a concrete individualization (' $X_{\mathrm{ADJ}} \rightarrow$ 'a person/animal/thing that is $X_{\text {SUBST }}$ ), or

(B) an abstract (' $X{ }^{\prime}{ }_{\mathrm{ADJ}} \rightarrow$ 'the state/quality/condition of being $X_{\text {SUBST }}$ )

In many cases, the abstract can simultaneously have a concrete meaning. This is nothing remarkable and can be observed in many modern-day examples of abstract-forming suffixes. Compare the English noun whiteness as in 'the quality or condition of being white in color' (the whiteness of the snow on the mountains), which can also be used in a concrete sense 'a white substance or part of something' or 'snow' (I tried to imagine the movie-set roofs piled with fluffy whiteness). ${ }^{12}$ This can also be observed in the classical languages. The substantivizing suffixes mentioned at the outset typically create substantivizations that have both meanings. ${ }^{13}$ For derived $i$-stems, compare, for example, the Latin nouns febris, -is f. 'fever' < * $d^{h} e g^{w h}$ ri- 'heat' (from * $d^{h} e g^{w h}-r o-$ 'hot'; cf. Gk. $\tau \varepsilon \dot{\varphi} \varphi \rho \alpha$ $\mathrm{f}$. 'ashes') and rauis, -is f. 'hoarseness' (from rauus 'hoarse') as abstracts, and ciuis, -is $\mathrm{m}$. 'citizen' < *keiui- 'member of the society' (from * $\hat{k}(e)$ ino- 'socially close'; cf. Ved. śéva-, śivá- 'auspicious, dear, friendly', PGmc. *heiwa- 'household', Latv. siẽva f. 'wife') or imber, -bris m. 'rain' (cf. Osc. dat. pl. anafríss 'imbribus') < * $n b^{h} r i-\mathrm{m}$. 'wet stuff' (from *no $b^{h}$-ró- 'wet'; cf. Ved. abhrá-n. 'rain-cloud', Gk. à $\varphi p o ́ s$

and change in ablaut it would be more precise to speak of morphological and/or morphonological 'effect'. For the sake of brevity, however, I will subsume all of the mentioned 'effects' under 'morphological effects' (with quotation marks).

11 Cf. Nussbaum (2014: 304-06).

12 Cf. $O E D$ (s.v. whiteness, n. meaning 1. a. and 1. b.) where the bracketed sample sentences are taken from.

13 Cf. Nussbaum (2014: 304-05). 
m. 'foam'). ${ }^{14}$ It is of no significance for now whether the abstract meaning was original and the concrete meaning developed from it, if it was the other way round, or whether both meanings were inherent in such formations simultaneously and the specialization of individual suffixes to create one or the other was a secondary development. At least from a theoretical perspective, the latter option seems to be the most plausible one if we interpret the PIE suffixes ${ }^{*}-(o) n-,{ }^{*}-(o / e) t-,{ }^{*}-i-,{ }^{*}-(e) h_{2-}$, etc. as analogous to determiners. ${ }^{15}$

When it comes to the formal side, the use of suffixes is actually only one of several ways to create a 'direct' substantivization. Apart from suffixation or suffix substitution (see the $i$-stem examples above), we find for example accent

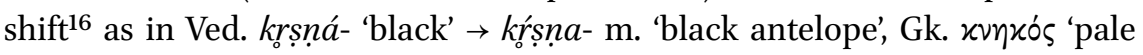
yellow, tawny' $\rightarrow$ xvîxos f. 'safflower' (Myc. ka-na-ko), etc. We can also observe a systematic change in ablaut, which for athematic adjectives is called 'internal derivation'17 as in "pum-és- 'having a beard' (>> Lat. pübēs, -eris 'pubescent; downy') $\rightarrow$ " $p(e ́) u m-\bar{o} s \mathrm{~m}$. 'the bearded one' (> Ved. púmāms- m. 'man'18) or in ${ }^{*} h_{2}(e) r g-i$ - 'bright, swift' (Hitt. harki- 'white, bright') $\rightarrow$ * $h_{2}$ érg-ōi f. 'the swift one' (Gk. 'Aprú, -óos f. 'Argo (name of a ship)'19). For thematic adjectives, something similar-i.e. a change in ablaut in the stem of the adjective-can be seen in substantivizations with a new accented $e$-grade ('Substantivierungsvrddhi' ${ }^{20}$ ), as in * $\hat{g}_{0} h_{1}$-tó- 'born' (Lat. ( $g$ )nātus 'son', Ved. jātá- 'born; son', ON kundr 'son') $\rightarrow$ *génh $h_{1}$ to- n. 'born one' (OHG kind, German Kind 'child'), or in substantivizations with a new accented $o$-grade, ${ }^{21}$ as in ${ }^{*} m r$-tó- 'mortal, dead' (Ved. $m r$ rtá-, Av.

14 On $i$-stem substantivizations cf. Schindler (1980: 39o); Weiss (1996: 204-05); Nussbaum (1998b: 523); Nussbaum (1999: 399); Nikolaev (2003: 187-88); Rieken (2005); Vine (2006); Weiss (2020: 334-35); Weiss (2013); Höfler (2015b: 228).

15 The two phrases mentioned above containing whiteness in an abstract and a concrete meaning, respectively, can easily be rewritten using a determiner (the, some) plus the substantivized adjective (white) as the white of the snow on the mountains and I tried to imagine the movie-set roofs piled with some fluffy white.

16 Cf. AiGr (III: 88); Nussbaum (1986: 157); Schaffner (2001: 328); Rau (2008: 165); Steer (2014: 397); Höfler (2017).

17 Cf. Schindler apud Peters (1980: 50); Nussbaum (1986: 118); Griepentrog (1995: 109-1051); Nussbaum (1998a: 147); Widmer (2004: 30-35 and 62-70); Höfler (2015a).

18 Cf. Adams (1985a); Höfler (2015a: 178-79). For the semantics cf. Lat. barbātus 'bearded' and Romanian bărbat 'man'.

19 Cf. Rau (2009: $\left.5^{2^{52}}\right)$.

20 Cf. Eichner (1973: $93^{46}$ ); Schindler apud EWAia (II: 269-70); Schaffner (1997: 10853); Schaffner (2001: 235-36 $6^{335}$ ); Lipp (2009 II: 416 $\left.{ }^{138}\right)$; Steer (2014: 397); Steer (2015: 33-34, 49, $76-77,165)$.

21 Cf. Schindler (1980: 390 ${ }^{17}$ ); Hamp (1982/83: 171-77); Nussbaum (1986: 8); Rasmussen (1989: 178); Neri \& Ziegler (2012: 27); Neri (2013: 197-98); Harðarson (2014: 473); Steer (2015: 100); Neri (2016: 24, 30, 32, 34, 40); Höfler (2018b). 


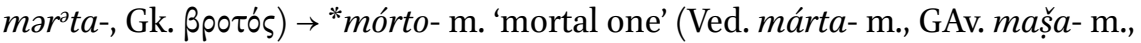

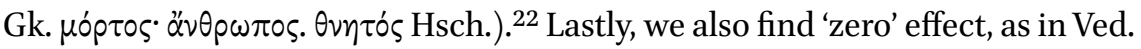

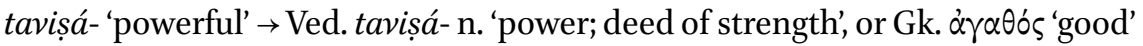

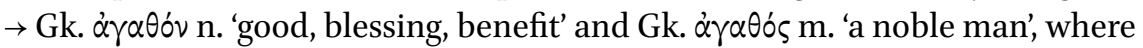
the only formal difference between adjective and substantive is the determination of the grammatical gender that accompanies the change of word class.

In the 'zero' case, the formal overlap with ellipsis-sourced substantivizations is obvious. Or, in other words: it is not quite clear from the outset whether a word like, e.g., Ved. vatsá- m. 'calf' continues a direct substantivization of the adjective *uet-s-ó- 'one year old'23 or whether it goes back to a syntagma of this adjective with an ellipted word for 'calf', 'steer', or '(young) animal'. This question might not seem overly relevant at first sight but it is, I think, of fundamental importance for our understanding of substantivization as a word-formation process.

\section{$4 \quad$ How to distinguish the two types?}

Unfortunately, there is no easy way to distinguish ellipsis-based substantivizations from direct substantivizations with no overt 'morphological effect'. Sometimes, however, there is circumstantial evidence from the semantic side to help decide whether a deadjectival formation belongs to the former or the latter group.

\subsection{Adjectival abstracts}

Adjectival abstracts, the type * $d^{h} e g^{w h}$-ro- 'hot' $\rightarrow{ }^{*} d^{h} e g^{w h} r i$ - 'heat' (Lat. febris, -is f. 'fever'), are always the result of a direct substantivization. Ellipses virtually never create such abstracts. Exceptions to this rule are only apparent: even if

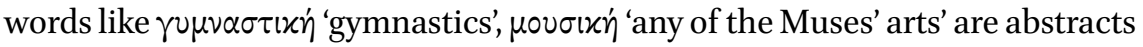
in the sense that they do not refer to concrete entities, they can hardly be interpreted as adjectival abstracts of a semantic structure ' $X$ ' ${ }_{\mathrm{ADJ}} \rightarrow$ 'the state/quality/condition of being $X_{\text {SUBST }}^{\prime}$.

22 The label 'change in ablaut' for both internal derivation and substantivization with a new accented $e$ - or $o$-grade does not necessarily imply that these processes and their respective origin have to be analyzed in the same way. Another caveat is that it is not clear how (or, indeed, if) the three types of substantivization of thematic adjectives-viz. plain accent retraction, new accented $e$-grade, new accented $o$-grade — are interrelated.

23 For the formal analysis of this adjective (i.e. possessive adjective 'having a year' or degenitival hypostasis 'of the year') see Vine (2009: 216-17; arguing for the latter). 


\subsection{Concrete referents or 'individualizations'}

The most prominent case of deadjectival substantivization as 'individualization' is in names. Deadjectival names are always 'direct' substantivizations, which is especially obvious in personal names like the already mentioned Catō and $\Sigma \tau \rho \dot{\alpha} \beta \omega \nu$ types; an ellipsis of uir or $\alpha \dot{\alpha} \theta \rho \omega \pi \circ \varsigma$ (or the like) is totally out of the question in these and any other cases of anthropological name-giving. This rule also extends to other names, like pet names (ג丷orós 'swift' $\rightarrow$ "Apros, Odysseus's

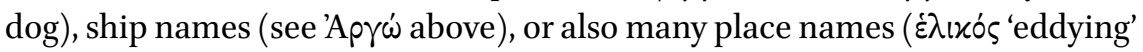
$\rightarrow$ E $\lambda$ ix , a town in Achaea), etc.

In the case where the substantivization is not a name but refers to a concrete referent, both types — the 'direct' and the ellipsis type-occur side by side and can usually be paraphrased as 'a/the $Y_{\mathrm{SUBST}}$ that is $X_{\mathrm{ADJ}}$ '. In the ellipsis type,

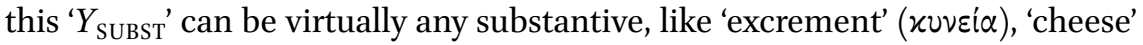

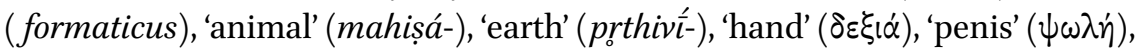

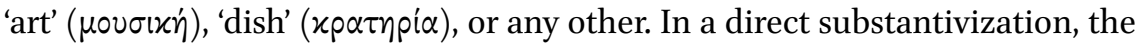
' $Y_{\text {SUBST }}$ ' is semantically more restricted and typically stands for a person (ciuis,

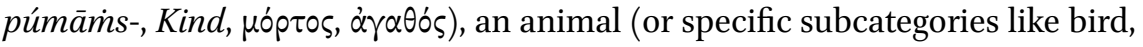
fish, antelope [kŕṣna-]), a plant ( $\varkappa v \eta \hat{\kappa} \times \varsigma)$, a tree for animate referents, and a thing, part, substance (imbris, $\alpha \gamma \alpha \theta o^{\prime}$ ) for inanimate referents, and besides that also an instrument or a disease. Compare the different Greek substantivizations (all with accent retraction) of the adjective $\lambda$ Euxós 'bright, white' that can

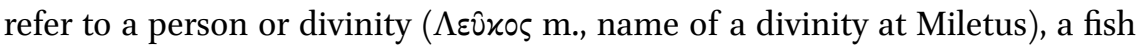

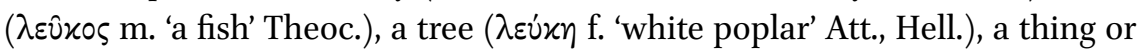
substance ( $\lambda \varepsilon \hat{x}$ «l f. pl. 'white spots on the nails' Alex. Aphr;; $\lambda \varepsilon u ́ x \eta$ f. 'white clay

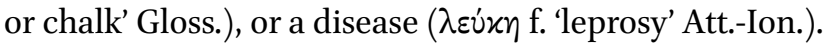

Another difference is that while ellipsis-based substantivizations are always resolvable as 'a/the $Y_{\text {SUBST }}$ that is $X_{\mathrm{ADJ}}$ ' or '(a/the) $X_{\mathrm{ADJ}} Y_{\text {SUBST }}$ (i.e. a syntagma that-by definition-is the ultimate source of this substantivization), a specific ' $Y_{\text {SUBST }}$ ' is often not needed in paraphrasing a direct substantivization; it is enough to think of 'the/a $X_{\mathrm{ADJ}}$ one', as is evident, for example, from the names listed above (e.g. 'Apr'́ < 'swift one'). ${ }^{24}$

In some direct substantivizations, ' $X_{\mathrm{ADJ}}$ ' is applicable for all ' $Y$ 's' and ' $X_{\mathrm{SUBST}}$ ' is a synonym or paraphrase of ' $Y$ '. Compare the adjective * $r o t-h_{2}-o$ - 'having wheels, wheeled' (derived from "rot-eh ${ }_{2}$ ' 'wheel', attested in Lat. rota f.) and its direct substantivization (with accent retraction) * $r o$ oth ${ }_{2} \mathrm{O}$ - 'the wheeled one'

24 In terms of underlying structure, one could interpret ' $X_{\mathrm{SUBST}}$ ' more generally as 'the/a $X_{\mathrm{ADJ}}$ one' and think of ' $Y$ ' as a silent empty noun (cf. Günther 2018: 99) whose underlying semantic representation can be rendered as 'person', 'animal', 'thing', or just 'one', depending on pragmatic context. 


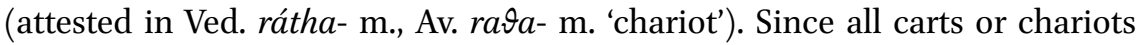
arguably possessed wheels, the substantive * ${ }^{*}{ }^{\prime} h_{2} o$ - 'the wheeled one' is a synonym or paraphrase of 'chariot'. No ellipsis of a word for 'cart' is, therefore, needed here. Similarly, the direct substantivization (with accent retraction) * $k r h_{2} s h_{2}$ - 'the horned one' (on the basis of *kr ${ }_{2} h_{2} s$-ó- 'horned', derived from *kér- $h_{2}-s$ n. 'horn', attested in Gk. xépas) is the source of PGk. *káraha $\mathrm{f}$. 'the horned one' > Cret. $x \alpha \dot{\alpha} p \bar{\alpha}$ f. 'tame goat' (Hsch.). ${ }^{25}$ Here, 'the horned one' is likewise a synonym or paraphrase of 'goat' since all goats (both male and female) have horns. ${ }^{26}$

In yet other cases, the direct substantivization is explicitly not resolvable as '(a/the) $X_{\mathrm{ADJ}} Y_{\mathrm{SUBST}}$ ', namely when the adjective ' $X_{\mathrm{ADJ}}$ ' does not necessarily apply to the semantic head as a whole, but rather only refers to one prominent feature of it. The term Lat. pānsa, -ae m., also used as a cognomen Pānsa (from pānsus 'spread out'), for instance, does not refer to a spread-out person but rather to someone with feet that are spread-out or splay. ${ }^{27} \mathrm{~A}$ similar case is scaeuus 'left' and scaeua m. 'left-handed person, lefty'. Another field where this feature can be observed nicely is in fish names. The English whitling 'a sea trout'

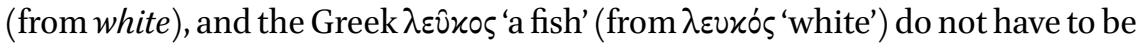
'white fish. The name can refer to a prominent white stripe or mark, white flesh, or a relative whiteness in relation to a darker or different-colored but other-

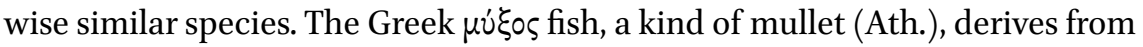
*muk-s-ó- 'slimy', ${ }^{28}$ but does not necessarily designate a 'slimy fish'. The name probably refers to the adipose eyelids that the family Mugilidae (or mullets) is known for. Lastly, the English fish name roughy (as in orange roughy) does not designate a 'rough fish', but rather a fish with large rough-edged scales. ${ }^{29}$

A special case of concrete referents is the formation of collectives and 'delibatives'. As convincingly argued by Nussbaum (2014: 277-88), the substantivization of possessive or genitival adjectives derived from (i) countable or

25 Cf. Nussbaum (1986: 156-57).

26 In contrast to goats, only the males of red deer have 'horns' or antlers, which is why derivatives of *kó/éru- 'horn' such as *keruo- (Lat. ceruus), *kruo- (Welsh carw), *kerud- (OHG hiruz, OE heorot), etc., originally only referred to the 'hart' or 'male cervid' ( $<$ 'the antlered one'), as argued by Adams (1985b: 274-75), the generic term for 'red deer' being ${ }^{*} h_{1} e l\left(h_{1}\right) e n$ (plus variants). Within Tocharian, the adjective ${ }^{*} k h_{2} h_{2} s-o$ - 'horned' is continued as TB karse 'hart, deer'.

27 Cf. Walde \& Hofmann (II: 248 s.v. pānsa).

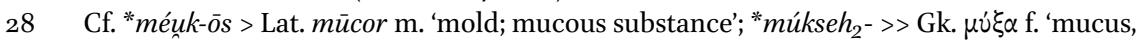
slime'. On the remodeling of inherited $\bar{a}$-stems to $\breve{a}$-stems in Greek see Solmsen (19o9: 238).

29 Cf. $O E D$ (s.v. roughy, n. meaning 2$)$. 
count nouns and (ii) uncountable or mass nouns can lead to the semantics of (i) a collective, i.e. 'a syntactic [and/or] ... morphological singular denoting a group of "identical" things,' ${ }^{30}$ and (ii) a delibative, i.e. 'a finite sample or ... a particular variety of the stuff in question,'31 respectively. For the collective type, compare Lat. arbōs 'tree' $\rightarrow$ arbustum n. 'copse, plantation' (thematic neuter in *-to-), and for the delibative type Lat. strāmen 'straw' $\rightarrow$ strāmentum n. 'bundle of straw' (thematic neuter in *-to-). ${ }^{32}$ These collectives/delibatives are also based on 'direct' substantivization processes, as can be seen from examples showing a 'morphological effect' such as accent retraction; compare Gk. àn 'mist, haze; air' ( ${ }^{*} h_{2}$ usếr 'morning thing') $\rightarrow{ }^{*} h_{2}$ usr-ó- (cf. Ved. usrá- 'matutinal')

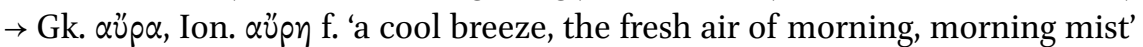
(quasi * $h_{2}$ úsreh ${ }_{2}$-in a delibative sense 'a bit of mist/air'), ${ }^{33}$ or *méuk-os n. 'slime' $\rightarrow$ *muk-s-ó- $\rightarrow$ *múkseh ${ }_{2}->$ Gk. $\mu$ í $\xi \alpha$ f. '(a bit of) mucus, slime' (see also note 28), a 'delibative' with plural forms attested since Hesiod.

These semantic deliberations should be seen as general tendencies rather than rigid rules. In many cases, of course, the distinction can be blurry. ${ }^{34}$ For the above-mentioned example Ved. vatsá- m. 'calf' (from *uet-s-ó- 'one year old'), for instance, no clear verdict can be decided. Semantically speaking, a syntagma 'one-year-old calf' with subsequent ellipsis is just as plausible as 'the oneyear-old one' as a direct substantivization. Any identification should, therefore, rely_if possible — on (a combination with) formal arguments rather than on semantic considerations alone.

\footnotetext{
$30 \quad$ Nussbaum (2014: 285$)$.

$31 \quad$ Nussbaum (2014: 278).

32 Examples taken from Nussbaum (2014: 290-92).

33 Cf. Nussbaum (2014: 297).

34 In some cases, the boundaries seem particularly fluid: there is a subtype of deadjectival 'direct' substantivizations that shares a specific feature with ellipsis-based substantivizations in that the gender of the substantivization is dependent on the gender of another word. But unlike in the ellipsis-case where the gender of the substantivized adjective depends on the ellipted word, the gender of this type depends on the gender of a semantically associated generic term or synonymous model word, or on a lexically determined gender restriction. Examples of the former type might be the already mentioned fish

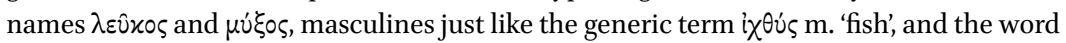
for 'palm (of the hand)' (see below in section 5) Lat. palma f., Gk. $\pi \alpha \lambda \alpha \mu \eta$ f., etc., whichas most words for 'hand' in the IE languages - is a feminine; an example of the lexically determined gender restriction type is Gk. $\lambda \varepsilon u ́ x \eta \mathrm{f}$. 'white poplar' that presumably owes its gender to the fact that most dendronyms in Greek are feminine (even though the generic term for 'tree', $\delta \dot{\varepsilon} v \delta \rho(\varepsilon) o v$, is neuter).
} 
In case of suffixation with substantivizing suffixes such as ${ }^{*}-(o) n-,{ }^{*}-(o / e) t-,{ }^{*} i-$, or *-k- (cf. *séno- 'old' $\rightarrow$ *sene- $k$ - m. 'old guy' > Lat. senex), it is obvious that we are dealing with a 'direct' substantivization, i.e. a substantivization that was intentionally created by a derivational process that consisted of adding a suffix to the stem of the adjective. The same holds true for other 'morphological effects' accompanying the substantivization, such as change of ablaut (internal derivation, substantivizations with a new accented $e$-grade, substantivizations with a new accented $o$-grade) and change of accentuation (accent shift), or a combination of them. This means that, by implication, these morphological processes are excluded from appearing in ellipsis-based substantivizations, which themselves — as already mentioned above-look still like adjectives on the surface. In other words, in ellipsis-based substantivizations there is no other formal process to mark or create the substantivization.

One group of words, in which these premises play a significant role, are formations in PIE *-(e-) $h_{2^{-}}$, which therefore deserve a more detailed treatment. For a substantive that can be traced back to a formation in which ${ }^{*}(e-) h_{2}-$ is seemingly attached to the stem of a thematic adjective, can be one of two things:

(A) the feminine of this thematic adjective, substantivized via ellipsis.

(B) a 'direct' substantivization of this adjective via the suffix ${ }^{*}-(e-) h_{2}-$. In (A), ${ }^{*}-(e-) h_{2}$ - is just an agreement marker added to the thematic adjective to express gender concord. In (B), however, the formant ${ }^{*} h_{2}$ - is an independent substantivizing suffix that attaches to the thematic vowel ${ }^{*} e-$ to create 'direct' substantivizations, i.e. either concrete individualizations (' $X{ }_{\mathrm{ADJ}} \rightarrow$ 'a person/animal/thing that is $X_{\text {SUBST }}^{\prime}$ ) or abstracts ( $X^{\prime}{ }_{\mathrm{ADJ}} \rightarrow$ 'the state/quality/condition of being $X_{\text {SUBST }}^{\prime}$ ). As a substantivizing suffix, ${ }^{*} h_{2}$ - was primordially not associated with feminine gender, which can be deduced not only from the rich evidence of Anatolian, ${ }^{35}$ but also from the masculines in Gk. $-\eta \varsigma /-\bar{\alpha} \varsigma$ (the type $\pi \circ \lambda \hat{i} \tau \eta \varsigma \mathrm{m}$. 'citizen'36), Lat. - $a$ (the type pānsa m. 'splay-footed man' from pānsus 'spread out', see above).

Within this second group of formations in *-(e-) $h_{2^{-}}$, 'morphological effects' such as the introduction of a new accented $e$-grade or $o$-grade, or plain accent

35 Cf. Hajnal (1994); Melchert (2014); Sasseville (2018).

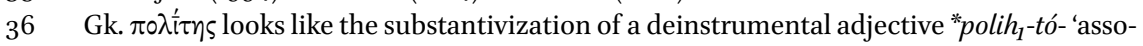
ciated with a $\pi \dot{o} \lambda$ ıs' (cf. Osthoff apud Einhauser 1992: 240) of the type reflected in Latin adjectives in -ïtus (as in Lat. aurîtus *'associated with ears' > 'having long or large ears (of a hare, donkey)' and 'attentive, listening', from auris f. 'ear'). 
shift, seem to be the rule. For the first type compare *tm $h_{x}-s-r o$ - 'dark' (Lith. tim̃sras, West-Aukšt. timsras 'dark red') $\rightarrow$ " tém $h_{x}$ sreh $_{2}$ - 'darkness' or 'dark thing' (Ved. támisrā- [f. pl. in $R V$ 2.27.14] 'the dark, a dark night', Lat. tenebrae f. pl.

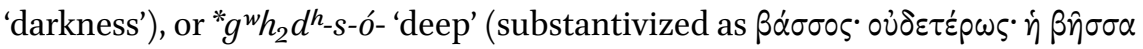
'(n.), combe, glen' Hsch.) $\rightarrow{ }^{*} g^{u} e h_{2} d^{h}{ }{ } h_{2}$ - f. 'depth; deep thing' (> Gk. $\beta \hat{\eta} \sigma(\sigma) \alpha$, Dor. $\beta \alpha \sigma \sigma \alpha$ f. 'wooded combe, glen' poet., Il.+). ${ }^{37}$ Substantivizations with a new $o$-grade can be seen, for example, in *luksnó- 'bright' (subst. as $\lambda u ́ x v o \varsigma$ m. 'lamp') or *leuksnó- 'bright' (YAv. raoxšna-, OHG liehsen 'bright') $\rightarrow$ *louksneh ${ }_{2}$-f. 'bright thing' (YAv. raoxšnā- 'light', Lat. lūna (Praenest. LOSNA), OCS luna 'moon', OPr. f. pl. lauxnos 'stars'38), or *tmo $h_{x}-s$-ó- 'dark' (Latv. tùmšs, timšs) or *temh $h_{x}-s-o ́$ - 'id.' (OS thimm), a possessive derivative of *tém $h_{x}$-os $\mathrm{n}$. 'darkness' (Ved. támas-, Lat. adv. temere 'thoughtlessly' < *'in darkness') $\rightarrow{ }^{*} t o m\left(h_{x}\right) s e h_{2}-$ f. 'darkness' (Lith. tamsà f. 'id.'). ${ }^{39}$

The type with plain accent retraction is more common than the two just mentioned ones. It can be seen in masculine substantivizations such as the Greek masculine stems in $-\eta \varsigma$ or $-\bar{\alpha} \varsigma\left(<{ }^{*}-e-h_{2}+s\right)$ that are as a rule not oxytone. ${ }^{40}$ This is true for both inner-Greek examples such as $\tau \alpha \chi$ ivós 'swift' (poet. and

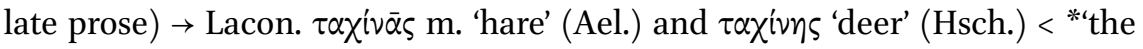
swift one', and for clearly old and/or even inherited pairs of formations, where the difference in accentuation led to different phonological outcomes, like in ${ }^{*} \mathrm{C} R h_{2} C$ sequences, where unaccented ${ }^{*} C R h_{2} C$ gave Gk. $C R \eta / \bar{\alpha} C\left({ }^{*} t l h_{2}-t o ́->\mathrm{Gk}\right.$.

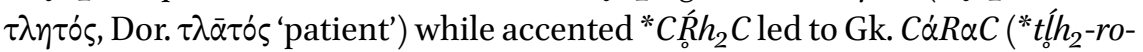
$>$ Gk. $\tau \dot{\alpha} \lambda$ apos m. 'basket'). ${ }^{41}$ One such doublet is the oxytone adjective * $d m h_{2}$ ló- 'tame(d)' > *dmāló- > Att.-Ion. $\mu \eta \lambda$ ós 'tame, gentle' (EM), Dor. $\mu \bar{\alpha} \lambda$ ós (Theoc. $e p$. 1.5; as an epithet of $\tau p \alpha$ ryos 'he-goat') and the barytone substantivization *dín $h_{2} l e h_{2^{-}}>$* dámala $( \pm s)>\delta \alpha \mu \alpha \dot{\lambda} \lambda \eta \varsigma \mathrm{m}$. 'young steer' (Arist., $\left.A P\right)<*$ the tamed [= castrated] one', $\delta \alpha \mu \alpha \dot{\alpha} \lambda$ s in a fragment of Anacreon (6th c. BCE) 'subduer' < *'the taming one. 42

Within feminine ${ }^{*}-e-h_{2}$-stems we find accent retraction in several textbook examples, both of einzelsprachlich date (the individualization type in Gk. $\lambda \alpha \pi \alpha-$

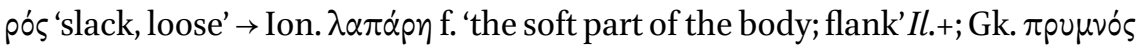
'hindmost, end-most' $\rightarrow$ Ion. $\pi \rho u ́ \mu \nu \eta$ f. 'hindmost part; stern'43 Il.+; Ved. kālaka-

\footnotetext{
37 Cf. Peters (1999).

38 OCS luna and OPr. lauxnos presuppose an o-grade.

39 Cf. Rasmussen (1989: 186).

40 Cf. Buck \& Petersen (1945: 2); Balles (2008: 203).

41 For this phonological development and the outcome for sequences with ${ }^{*} h_{1}$ and ${ }^{*} h_{3}$ see the discussion in Höfler (2016/2017 [2019]) with references to earlier literature.

42 For the details cf. Höfler (2016/2017[2018]).

43 On the accentuation of these words in the Homeric manuscripts cf. West (1998 I: XXI).
} 


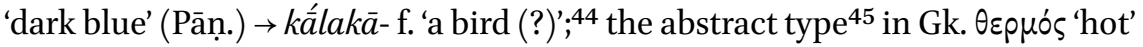

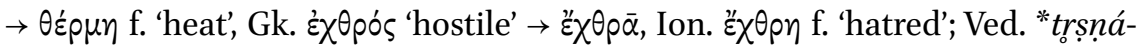
'thirsty' (< "trss-nó- 'dried up'46) $\rightarrow$ Ved. tŕs ș̣na-f. 'thirst'), and in inherited formations, like for example "p! $h_{2} m e h_{2}$ - 'the broad one' > Gk. $\pi \alpha \lambda \alpha \mu \eta$ f. 'palm (of the hand)', Lat. palma f. 'palm of the hand'; ${ }^{47}$ or * $h_{2}$ enkuló- 'curved' (Gk. àrivizos 'id.' with Wheeler's Law) $\rightarrow{ }^{*} h_{2}$ énkule $h_{2}$ ' 'curved thing' (Gk. $\alpha \gamma x u$ ' $\lambda \eta \mathrm{f}$. 'bend of the arm; thong of a javelin', OIcel. ól f. 'thong', OE oll(-pwang) 'id.'48); or * ieh ${ }_{3} s$ -

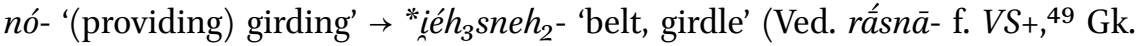

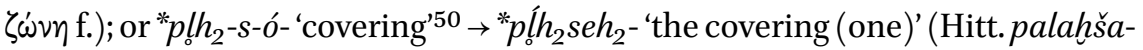
/ palhša-/ c. 'a garment for women; a cloth covering', PItal. "palasā > Lat. palla f. 'women's garment; a curtain' Plaut.+). Note that the latter example secures the existence of this type in PIE (including Anatolian). ${ }^{51}$

On the other hand, however, ${ }^{*}-e-h_{2}$-stems can likewise continue substantivizations of the feminine forms of thematic adjectives with an ellipsis of the noun that this adjective was paired with in a former syntagma. Since this was not a spontaneous and deliberate, but rather a gradual process, we can assume that the adjective typically remains unchanged and keeps its original accentuation as in the examples from above: $\delta \varepsilon \xi 1 \alpha$ f. 'right hand', $\gamma \nu \mu \nu \alpha \sigma \tau i x \eta$ ' f. 'gymnastics', $\psi \omega \lambda \eta$ f. 'phallus', etc. Another example from Greek that authorizes such an interpretation is $\sigma \tau \rho \omega \mu \nu \eta$ f. 'a bed spread or prepared; bed, couch' (Sapph., Pi., Att. etc.). The formation presupposes an adjective * $\sigma \tau \rho \omega \mu \nu o ́ s ~ ' s p r e a d$ ' derived from $\sigma \tau p \omega \hat{\omega} \mu \alpha$ n. 'anything spread or laid out for lying or sitting upon' (Att. Ion.) < ${ }^{*}{ }^{2} t r h_{3}$-men- n. 'spreading, spread-out thing', in the same way that हैpu-

44 Cf. EWAia (I: 344).

45 Cf. Kuryłowicz (1968: 91); Pinault (2011: 174); Dieu (2016: 148-49).

46 Cf. also Av. taršna- m. 'thirst', Sanskr. trșnaka- 'desirous, eager'.

47 Further cognates include: PCelt. *lāmā-(OIr. lám f., MW llaw), PGmc. *fulmō- (OE folm f., OHG folma f.). According to Matasović (2012: 137), PCelt. *lāmā- also presupposes a barytone pre-form. On the development ${ }^{*} C \stackrel{{ }_{0}}{h_{2}} C>$ Lat. $\mathrm{CaR}(a) C$ (the 'palma rule') see Höfler (2017).

48 Cf. Schaffner (2001: 371) with a slightly different account of Gk. $\dot{\alpha} \gamma x \dot{\lambda} \lambda \eta$.

49 With analogical $r$ - for * $y$ - after raśaná-f. 'rope; girdle' (see EWAia II: 350).

$5^{\circ} \quad$ A possessive derivative based on the neuter $s$-stem * $p e ́ l h_{2}-(o) s \mathrm{n}$. 'cover(ing)' (Gk. ${ }^{\circ}-\pi \varepsilon \lambda \alpha \varsigma$ n. 'skin'; denominal verb Umbr. pelsa- 'bury'); cf. Weiss (2010: 305).

$5^{1}$ It might be worth mentioning here in all brevity that PIE seems to have also known a substantivizing accent 'protraction', namely when the underlying adjective was barytone. Compare the following direct substantivizations of barytone relational *-io- adjectives:

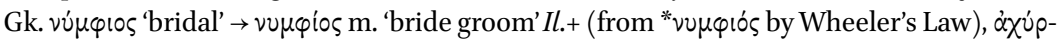

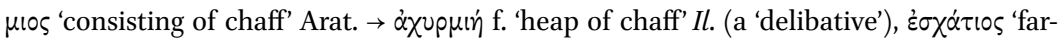

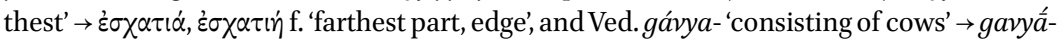
f. 'herd of cows' (a 'collective'). 


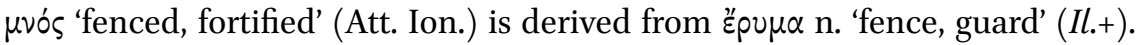

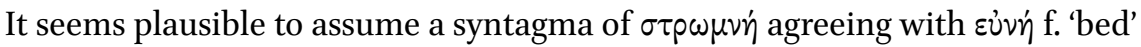
or $x \lambda i v \eta \mathrm{f}$. 'couch', which originally referred to a specific type of bed or bed-

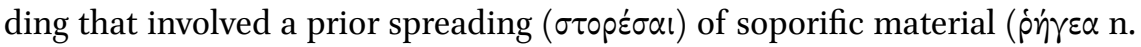
pl. 'blankets', $\tau \alpha \dot{\pi} \pi \eta \tau \varepsilon \varsigma \mathrm{m}$. pl. 'quilts', $\chi \lambda \alpha \hat{\imath} \nu \alpha \mathrm{l}$ f. pl. 'coverlets') over the bedstead

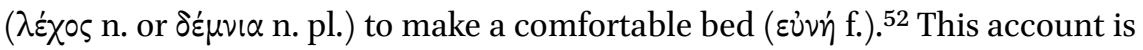
more economical than to assume a 'direct' substantivization of the adjective qua 'spread thing', or some sort of collective in ${ }^{*}-\bar{a}$ with a meaning '(collection of) spreading material' or similar. The only caveat in the ellipsis-based account

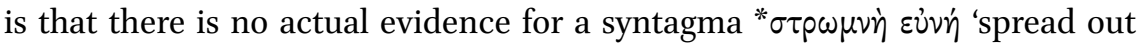
bed'.

However, it is even more difficult, nay impossible to prove an ellipsis at the PIE level. Any argumentation in this direction must necessarily depend on circumstantial evidence, generalizing assumptions, and basic semantic considerations. ${ }^{53}$ A possible example, though, is the word for 'wool', PIE * $h_{2} u u_{0} h_{1} n e ́ h_{2}-.54$ The majority of continuants suggests oxytone accentuation: Lat. lāna (without palma treatment; see note 47 ), Gk. * $\lambda \eta \nu \eta,{ }^{55} \mathrm{MW}$ gwlan, OIr. olann from

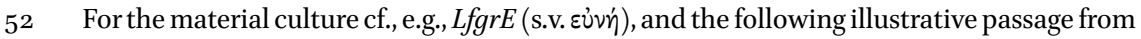

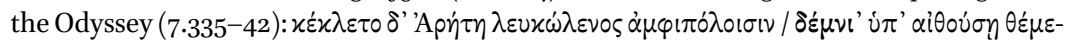

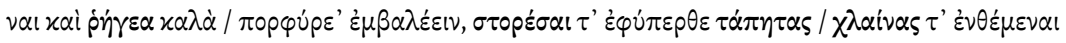

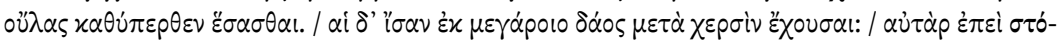

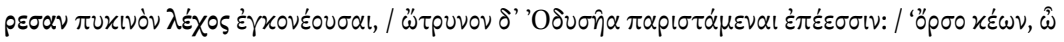

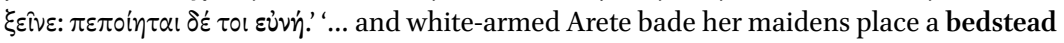
under cover of the portico, and to lay on it fair blankets of purple, and to spread there over coverlets, and on these to put fleecy cloaks for clothing. So they went forth from the hall with torches in their hands. But when they had busily spread the stout-built bedstead, they came to Odysseus, and called to him, and said: "Rouse thee now, stranger, to go to thy rest; thy bed is made."' (transl. by A.T. Murray, Loeb Classical Library).

53 Certain feminine $o$-stems of PIE pedigree could be identified as ellipsis-based substantivizations if we assume that their origin predates the emergence of feminine (i.e. ${ }^{*}-e h_{2}$-) agreement of thematic adjectives. One potential example is the word for the 'daughterin-law', * snusó-f. (Gk. vvós f., Arm. now, Lat. nurus, -ūs f. remodeled as an $u$-stem). It is the most promising account, I think, to depart from an s-stem *snéu-os $\mathrm{n}$. '(connubial) bond', derived from a root $* \sqrt{s n e u}$ 'to marry' (cf. the enlarged root variant $* \sqrt{s n e u}+b^{h}$ 'to marry (a man)' in Lat. nūbō, nūpsī 'marries/d (a man)', Russ.-CS. snubiti 'to marry off'), that formed an adjective *snu-s-ó- 'having a connubial bond; related through marriage' and was used in a syntagma * snusós $d^{h} u g h_{2}$ tếr 'a daughter by marriage' = 'daughter-in-law', in which the term for 'daughter' was eventually ellipted.

54 An insightful discussion of the evidence has recently been conducted by Pinault (2016: 241-42).

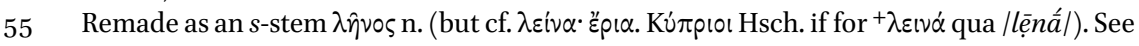
Peters (1987) as well as Peters (1980: $23^{18}$ ) for the loss of the anlauting laryngeal. 
PCelt. * "ulanā and (with different syllabification) *ulanā (Dybo's law ${ }^{56}$ ), PGmc. *wullō- f. (Goth. wulla, OHG wolla, etc. ${ }^{57}$ ). Lith. vilna f. (1) and SCr. vüna (cf. OCS $v(z n a),{ }^{58}$ as well as Hittite hulana- c. 'wool'59 are not informative, while barytone Ved. úrnāa- might owe its accent to analogical influence. ${ }^{60}$ Formally, ${ }^{*} h_{2} u l h_{1} n e ́ h_{2}$ - could be identified as the adjective ${ }^{*} h_{2} u l h_{1}-n o ́-$, a derivative of the root $* \sqrt{h_{2}}$ uelh $_{1}$ 'to pluck' (as in Lat. uellere 'pluck', Alb. vjel 'plucks'). It is conceivable to see in it a verbal adjective with a meaning 'plucked' 61 that was used in combination with a head noun for 'animal hair, wool' as the term for 'plucked wool, fleece'. Perhaps this 'plucked wool' deserved to be named explicitly in contrast to wool that the animals molted each spring without plucking and that was collected from the ground or shrubs. ${ }^{62}$ An ellipsis-based substantivization process would then have led to the use of ${ }^{*} h_{2} u l_{0} h_{1} n e h_{2}$ - as the standard word for 'wool'. Of course, however, it cannot be proven beyond doubt that ${ }^{*} h_{2} u l h_{1} n e ́ h_{2}$ - actually goes back to such a syntagma. But again, the

56 Dybo's Law in Celtic per Matasović (2012). Matasović does not, however, include the 'wool' word in his list of examples. For a discussion of OIr. olann and MW gwlan cf. also Zair (2012: 76 and 87). According to Schumacher (2004: $136-38)^{*} C R H T$ (with $T=$ any dental) would result in ${ }^{*} C R a \breve{T}$ irrespective of the position of the accent.

57 At least according to Kroonen (2013:598-99) who expects a sequence *-ln-to be preserved post-tonically.

58 A barytone ${ }^{*} h_{2} u l_{0} h_{1} n e h_{2}$ - would have straightforwardly led to the attested forms, while oxytone ${ }^{*} h_{2} u l h_{1} n e ́ h_{2}$ - would have undergone laryngeal-caused retraction of the accent to give Lith. vilna and BCS vüna (cf. " ploth $_{1}$ ó- 'full' > Lith. pilnas, Serbo-Croatian pün). See Jasanoff (2017: 80).

59 The exact interpretation of hulana-in relation to PIE $h_{2}{ }_{n} u_{0} h_{1} n e h_{2}$ - is a matter of debate but there can be no doubt that this word goes back to the same preform eventually. Melchert (1994: 65-66) proposes the following chronology of Proto-Anatolian sound developments: first, ${ }^{*} \mathrm{CuRC}$ develops to ${ }^{*} \mathrm{CuRC}$, then inherited ${ }^{*}$ - $n$ - clusters undergo assimilation (as in ${ }^{*} h_{2 / 3}$ ul-ne- $h_{1}->$ hulle- 'fight'), and only thereafter, ${ }^{*} h_{1}$ is lost between consonants, resulting in *hulna- with a 'new' sequence *-ln- that does not assimilate but rather develops an anaptyctic vowel (Hitt. hulana-). The supposition that interconsonantal ${ }^{*} h_{1}$ is lost only after certain Proto-Anatolian assimilatory processes had already taken place is, in my view, corroborated by Hitt. genzu- n. 'lap' reflecting * genh ${ }_{1} s u$ - (cf. Eichner 1973: 55, 8614; Höfler 2018a: $\left.122^{3}\right)$, which shows a different outcome from old ${ }^{*}$-ns- sequences $\left(\right.$ as in ${ }^{*} h_{2} e /$ onsu$>$ haššu- 'king').

6o Dieu (2016: 392-98) makes the important observation that almost all Vedic nouns in $-n \bar{a}-$ are barytone (cf., e.g., sthứña- f. 'post, pillar', sénā- f. 'missile, spear', víṇa- f. 'lute', rá́snāf. 'girdle', etc.), which could have encouraged an analogical accent retraction in *ūrṇá-< * $h_{2} u \iota_{\circ} h_{1} n e ́ h_{2}-$.

61 Cf. the references in Pinault (2016: $\left.247^{37}\right)$.

62 Cf. Mallory \& Adams (1997: 648-49 s.v. wool) for the material culture. Pinault has recently suggested to analyze the 'wool' word as a compound ${ }^{*} h_{2 / 3}$ ul- $h_{1}$ no-, literally 'making the year of/with fleece' (Pinault 2016: 251), the formation and semantics of which are not quite clear to me. 
explanation just given might be a more plausible account than to assume that the adjective 'plucked' was directly substantivized to 'plucked thing' or that *- $h_{2}$ - was used to form some sort of collective such as 'collection of plucked material. ${ }^{63}$ Other oxytone stems in ${ }^{*}$-é $h_{2}$ - for which the explanation as ellipsisbased substantivizations of thematic adjectives seems like the more plausible alternative include * $h_{2} e h_{1} s e ́ h_{2}$ - 'ashy (place)' (Hitt. hā̄ššā- c. 'fireplace, hearth', Lat. āra f. 'altar') and * $h_{2} i_{1 / 3} s e ́ h_{2}$ - 'thill- (pole)' (Hitt. hiššsa- c., Ved. ịsấ- f.), though a discussion of these examples would go beyond the scope of this paper.

A clearer picture emerges from some 'doublets', i.e. from instances where it is possible to identify both a 'direct' and an ellipsis-based substantivization of one and the same adjective in the individual languages. One case in point is the pair Ved. varșấ-f. 'rainy season' ( $A V+)$ and Gk. ċépon f. 'dew' (ep. poet. Il.+). Both nouns can be seen as a substantivization of the adjective * $h_{2}$ uersó- 'rainy, wet' (cf. Ved. varșá- $\mathrm{n}$. 'a rain' $R V+$ ). ${ }^{64}$ However, the seemingly parallel formations do not only differ in meaning, but also in the position of the accent. ${ }^{65}$ For Greek, the preservation of *-rs- as - $\rho \sigma$ - after the accented vowel ${ }^{66}$ points towards an immediate preform *auérs $\bar{a}<{ }^{*} h_{2}$ uérse $h_{2}$-, while Ved. varșá́- seems to continue an oxytone ${ }^{*} h_{2}$ uersé $_{2^{-}}$, at least without having to invoke additional hypotheses. In combination with the semantic mismatch of the two terms, we could be tempted to identify * $h_{2}$ uérse $h_{2}$ - as a 'direct' substantivization 'moisture' (Gk. képon 'dew') on the one hand, and Ved. varșấ- 'rainy season' (from virtual ${ }^{*} h_{2} u_{n}$ ersé ${ }_{2}-$ ) as an ellipsis-based substantivization on the other, namely from a syntagma with a feminine word for 'season, time of the year', like for example (the precursor of) Ved. sámā- $\mathrm{f}$. 'year, half-year, season' $(R V+)$, originally *'summer' (cf. YAv. ham- 'id.').

Another 'doublet' comes from Germanic, where we find continuants of both a PGmc. *wranhō- f. 'crook' and a PGmc. *wrangō-f. 'rib (of a ship)'. Either formation can be interpreted as a substantivization of the adjective PIE *uronkó-

63 The 'collective' (or rather: mass noun) meaning of the word * $h_{2} u$ l $h_{1} n e ́ h_{2}$ - might rather be due to the 'collective' (or rather: mass noun) meaning of the ellipted head noun ('animal hair, wool').

64 Cf. Nussbaum (2017: 255-56).

65 For Dieu (2016: 113-14, 380-81) —and also Nussbaum (2014: 299; 2017: 256)—the barytone

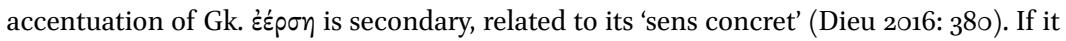
were, however, the accent retraction would have to predate the first compensatory lengthening, see immediately in the text and the next note.

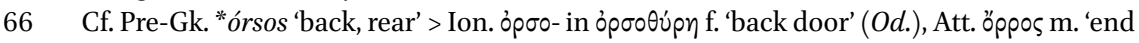
of the os sacrum' (cf. OHG ars m., OE ears, 'arse', Arm. or ) and Pre-Gk. *orsá f. 'the back, the rear' > Ion. ovjṕ f. 'tail; rearguard'. 
'curved, bent, crooked' > PGmc. *wranga- (OIcel. rangr 'crooked, wrong', OE wrang 'wrong, twisted, uneven', Mod. E. wrong), but within the framework outlined in this paper the formation PGmc. "wranhō- can be seen as the continuant of a barytone, 'direct' substantivization * urónkeh $_{2}$ - qua abstract 'crook, bend, curve' that led to OIcel. rá, ró f. 'corner, nook', Swed. vrå 'id., while PGmc. "wrangō- is an oxytone, adjective-sourced substantivization *uronké $h_{2}$, attested in OIcel. rong f. 'rib (of a ship)', Icel. röng f., Swed. vrang. The latter probably originated in an ellipsis of a feminine word for 'beam, wood' in the meaning 'curved (wood)' > 'rib'.67

The mentioned examples, therefore, seem to be in line with the proposition made above that ${ }^{*}-h_{2}$ - as a substantivizing suffix created 'direct' substantivizations and induced retraction of the accent ( \pm new ablaut grades) in the stem of the underlying thematic adjective, while in ellipsis-based substantivizations the accentuation of the underlying thematic adjective-in these cases agreeing with a substantive ending in ${ }^{*}-h_{2}{ }^{68}$ - was left unchanged. ${ }^{69}$ This led to the existence of barytone and oxytone ${ }^{*}-e h_{2}$-stems side by side. It must be stressed in this respect, however, that this rule of thumb only applies to 'secondary' * $-e h_{2}$-stems, i.e. those that are derived from thematic adjectives; the argument presented here does not apply to seemingly 'primary' * $-e h_{2}$-stems like the ver-

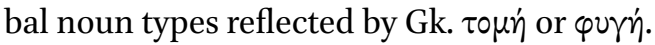

The aim of this paper was to establish a distinction between two basic processes of substantivization in PIE and the IE languages, namely between 'direct' substantivizations and substantivizations via ellipsis, and to outline the basic similarities and the fundamental differences between these two mechanisms. I argued that a 'morphological effect' (i.e. suffixation or suffix substitution, change in ablaut, accent shift, or a combination of them) in the substantivization vis-à-vis the underlying adjective is indicative of the former process, while in ellipsis-based substantivizations the substantivization looks just like the adjective of an erstwhile noun phrase, in which this adjective agreed with a subsequently ellipted substantive. This broad rule is only somewhat tarnished by a subgroup of 'direct' substantivizations that show no 'morphological effect'

\footnotetext{
67 For the philological details cf. Schaffner (2001: 418-20 with notes).

68 I refrain from invoking a specifically 'feminine' agreement here. See also below in the Conclusion.

69 Cf. in nuce Dieu (2016: 152) for Greek.
} 


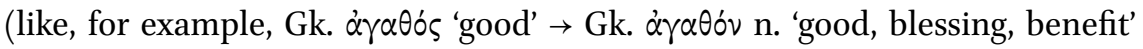
and Gk. àratós m. 'a noble man'); however, the semantic considerations outlined in section 4 might be able to serve as a guideline for their categorization. Regarding stems in * $-e-h_{2}$ - that can be seen as either 'direct' substantivizations of thematic adjectives or as feminine adjectives substantivized by ellipsis, I argued that the same rules apply: if the deadjectival stem in * $-e-h_{2}$ - is barytone, it is of the former, if oxytone, of the latter type. A couple of handbook examples of secondary oxytone * $-e-h_{2}$-stems (as, for example, the 'wool' word) are reconstructible for PIE including Anatolian, which means that this hypothesis might have repercussions on our understanding of adjectival agreement in the proto-language. However, this will have to await another occasion.

\section{Acknowledgments}

This paper was written as part of the project ' $O$ f beasts and men. The animals of the Proto-Indo-Europeans', which receives funding from the European Union's Horizon 2020 research and innovation program under the Marie SkłodowskaCurie grant agreement No. H2O2O-MSCA-IF-2018-835954. I thank Jay Jasanoff, Marek Majer, Melanie Malzahn, Martin Peters, and Jeremy Rau, as well as one reviewer for comments and suggestions, but no endorsement of any specific ideas is hereby implied. An extended version of this paper was presented at the Arbeitstagung der Indogermanischen Gesellschaft '100 Jahre Indogermanistik an der Universität Ljubljana: Ein "Ljubljäum"' (4.-7.6.2019) and I am grateful to the participants for the ensuing discussion. The work on the presentation was funded within the Post-DocTrack Program of the OeAW.

\section{References}

Adams, Douglas Q. 1985a. Sanskrit púmān, Latin pūbēs, and related words. Die Sprache 31/1: 1-16.

Adams, Douglas Q. 1985b. Designations of the cervidae in Proto-Indo-European. Journal of Indo-European studies 13: 269-81.

AiGr:Jacob Wackernagel.1896-1954. Altindische Grammatik. 3 vols. Göttingen:Vandenhoeck \& Ruprecht.

Balles, Irene. 2008. Nominale Wortbildung des Indogermanischen in Grundzügen. Die Wortbildungsmuster ausgewählter indogermanischer Einzelsprachen. Band 1, Latein, Altgriechisch. Hamburg: Dr. Kovač.

Buck, Carl Darling, \& Walter Petersen. 1945. A reverse index of Greek nouns and adjec- 
tives, arranged by terminations with brief historical introductions. Chicago: University of Chicago Press.

Dieu, Éric. 2016. L'accentuation des noms en *-ā $\left({ }^{*}-\mathrm{eh}_{2}\right)$ en grec ancien et dans les langues indo-européennes. Étude morphologique et sémantique. Innsbruck: Innsbrucker Beiträge zur Sprachwissenschaft.

Eichner, Heiner. 1973. Die Etymologie von heth. mehur. Münchener Studien zur Sprachwissenschaft 31: 53-107.

Einhauser, Eveline. 1992. Lieber freund ... Die Briefe Hermann Osthoffs an Karl Brugmann, 1875-1904. Trier: Wissenschaftlicher Verlag Trier.

EWAia: Manfred Mayrhofer. 1992-2001. Etymologisches Wörterbuch des Altindoarischen. 3 vols. Heidelberg: Winter.

Fraenkel, Ernst. 1910-12. Geschichte der griechischen Nomina agentis auf - $\eta^{\prime} \rho,-\tau \omega \rho,-\tau \eta \varsigma$ $(-\tau-) .2$ vols. Straßburg: Trübner.

Griepentrog, Wolfgang. 1995. Die Wurzelnomina des Germanischen und ihre Vorgeschichte. Innsbruck: Innsbrucker Beiträge zur Sprachwissenschaft.

Günther, Christine. 2018. The rich, the poor, the obvious-Arguing for an ellipsis approach to "adjectives used as nouns". In The noun phrase in English-Past and present, eds. Alex Ho-Cheong Leung \& Wim van der Wurff, 77-112. Amsterdam \& Philadelphia: Benjamins.

Hajnal, Ivo. 1994. Die lykischen $a$-Stämme: Zum Werdegang einer Nominalklasse. In In honorem Holger Pedersen. Kolloquium der Indogermanischen Gesellschaft vom 26.28. März 1993 in Kopenhagen, eds. Jens E. Rasmussen \& Benedicte Nielsen, 135-71. Wiesbaden: Reichert.

Hamp, Eric P. 1982/83. Indo-European substantives in *-mó- and *-má-. Zeitschrift für vergleichende Sprachforschung 96: 171-77.

Harðarson, Jón Axel. 2014. Zur Entwicklung der neutralen s-Stämme im Germanischen. In Munus amicitiae. Norbert Oettinger a collegis et amicis dicatum, eds. H. Craig Melchert, Elisabeth Rieken, \& Thomas Steer, 46-63. Ann Arbor \& New York: Beech Stave.

Höfler, Stefan. 2015a. Ist der Wettergott ein Himmelsgott? Indogermanische Götternamen und ihr Beitrag zur internen Derivation. In Grazer Symposium zur indogermanischen Altertumskunde. "Der Mensch im Spannungsfeld zwischen Ritual und Magie", eds. Christian Zinko \& Michaela Zinko, 148-89. Graz: Leykam.

Höfler, Stefan. 2015b. Denominale Sekundärderivation im Indogermanischen: Eine Ochsentour. Münchener Studien zur Sprachwissenschaft 69/2: 219-43.

Höfler, Stefan. 2016/2017 [2018]. Eine Notiz zum Hyperdorismus $\mu \hat{\alpha} \lambda \alpha$ 'Kleinvieh' bei Theokrit. Die Sprache 52/1: 1-18.

Höfler, Stefan. 2016/2017 [2019]. "La belle Hélène”, a generic brothel, and the development of * ${ }^{*} R H C$ sequences in Ancient Greek. Die Sprache 52/2: 177-201.

Höfler, Stefan. 2017. Observations on the palma rule. Pallas-Revue d'études antiques 103: $15^{-23}$. 
Höfler, Stefan. 2018a. Die anatolischen $s$-Stämme: Flexivischer Archaismus oder Kategorie im Zerfall? In 100 Jahre Entzifferung des Hethitischen. Morphosyntaktische Kategorien in Sprachgeschichte und Forschung, eds. Elisabeth Rieken, Ulrich Geupel, \& Theresa Maria Roth, 121-35. Wiesbaden: Reichert.

Höfler, Stefan. 2018b. The Caprice of $O$.... On a Proto-Indo-European substantivization type and its excesses in Ancient Greek. Paper presented at the 37th East Coast IndoEuropean Conference, in Ann Arbor, Michigan, 15-17 June 2018.

Huddleston, Rodney. 1988. English grammar: an outline. Cambridge: Cambridge University Press.

Jasanoff, Jay H. 2017. The prehistory of the Balto-Slavic accent. Leiden: Brill.

Kroonen, Guus. 2013. Etymological dictionary of Proto-Germanic. Leiden: Brill.

Kuryłowicz, Jerzy. 1968. Indogermanische Grammatik. II. Akzent und Ablaut. Heidelberg: Winter.

LfgrE: Bruno Snell \& Thesaurus Linguae Graecae Project. 1979-2010. Lexikon des frühgriechischen Epos. 4 vols. Göttingen: Vandenhoeck \& Ruprecht.

Lipp, Reiner. 2009. Die indogermanischen und einzelsprachlichen Palatale im Indoiranischen. 2 vols. Heidelberg: Winter.

Mallory, James P. \&, Douglas Q. Adams. 1997. Encyclopedia of Indo-European culture. London \& Chicago: Fitzroy Dearborn.

Matasović, Ranko. 2012. Dybo's law in Proto-celtic [sic]. Zeitschrift für celtische Philologie 59: 129-41.

Melchert, H. Craig. 1994. Anatolian historical phonology. Amsterdam: Rodopi.

Melchert, H. Craig. 2014. PIE *-eh ${ }_{2}$ as an "individualizing" suffix and the feminine gender. In Studies on the collective and feminine in Indo-European from a diachronic and typological perspective, eds. Sergio Neri \& Roland Schuhmann, 257-71. Leiden: Brill.

Neri, Sergio. 2013. Zum urindogermanischen Wort für ,Hand'. In Multi Nominis Grammaticus. Studies in classical and Indo-European linguistics in honor of Alan J. Nussbaum on the occasion of his sixty-fifth birthday, eds. Adam I. Cooper, Jeremy Rau, \& Michael Weiss, 185-205. Ann Arbor \& New York: Beech Stave.

Neri, Sergio. 2016. Review of Kroonen 2013. Kratylos 61: 1-51.

Neri, Sergio \& Sabine Ziegler. 2012. »Horde Nöss«: Etymologische Studien zu den Thüringer Dialekten. Bremen: Hempen.

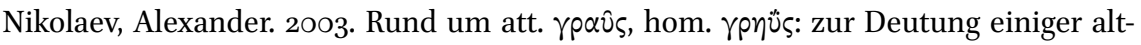
griechischer Personennamen. In Colloquia Classica et Indogermanica III, ed. Nikolai N. Kazansky, 179-98. St. Petersburg: Nauka.

Nussbaum, Alan J. 1986. Head and horn in Indo-European. Berlin: de Gruyter.

Nussbaum, Alan J. 1998a. Two studies in Greek and Homeric linguistics. Göttingen: Vandenhoeck \& Ruprecht.

Nussbaum, Alan J. 1998b. Severe problems. In Mír curad. Studies in honor of Calvert 
Watkins, eds. Jay H. Jasanoff, H. Craig Melchert, \& Lisi Oliver, 521-38. Innsbruck: Innsbrucker Beiträge zur Sprachwissenschaft.

Nussbaum, Alan J. 1999. *Jocidus: An account of the Latin adjectives in -idus. In Compositiones indogermanicae in memoriam Jochem Schindler, eds. Heiner Eichner \& Hans Christian Luschützky, 377-419. Praha: Enigma.

Nussbaum, Alan J. 2014. Feminine, abstract, collective, neuter plural: Some remarks on each (expanded handout). In Studies on the collective and feminine in Indo-European from a diachronic and typological perspective, eds. Sergio Neri \& Roland Schuhmann, 273-306. Leiden: Brill.

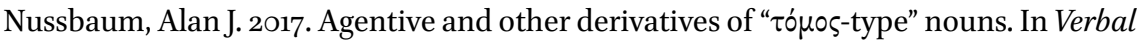
adjectives and participles in Indo-European languages, eds. Claire Le Feuvre, Daniel Petit, \& Georges-Jean Pinault, 233-66. Bremen: Hempen.

OED: Simpson, John \& Edmund Weiner. The Oxford English dictionary. 2nd edition. 20 vols. Oxford: Clarendon (https://www.oed.com; last access 5 December 2019).

Panagl, Oswald. 1989. Bahuvrīhi, Ellipse, Synekdoche. In Indogermanica Europaea. Festschrift für Wolfgang Meid zum 6o. Geburtstag am 12. 11. 1989, eds. Karin Heller, Oswald Panagl, \& Johann Tischler, 185-92. Graz: Institut für Sprachwissenschaft.

Peters, Martin. 1980. Untersuchungen zur Vertretung der indogermanischen Laryngale im Griechischen. Wien: Verlag der Österreichischen Akademie der Wissenschaften.

Peters, Martin. 1987. $\lambda \hat{\eta} v o$ aus $^{*} h_{2 / 3}$ ullo $h_{1} n a ́ h_{2}$-. Die Sprache 33/1-2: 114-15.

Peters, Martin. 1999. Ein tiefes Problem. In Compositiones indogermanicae in memoriam Jochem Schindler, eds. Heiner Eichner \& Hans Christian Luschützky, 447-56. Praha: Enigma.

Pinault, Georges-Jean. 2011. L'origine déictique du genre féminin en indo-européen. Bulletin de la Société de Linguistique de Paris 106/1: 129-82.

Pinault, Georges-Jean. 2016. Hittite and Indo-European wool. In Anatolica et Indogermanica. Studia linguistica in honorem Johannis Tischler septuagenarii dedicata, eds. Henning Marquardt, Silvio Reichmuth, \& José Virgilio García Trabazo, 241-55. Innsbruck: Innsbrucker Beiträge zur Sprachwissenschaft.

Rau, Jeremy. 2008. YAv. haosrauuah- and dāuš.srauuah-. Historische Sprachforschung 120: 159-68.

Rau, Jeremy. 2009. Indo-European nominal morphology. The decads and the Caland system. Innsbruck: Innsbrucker Beiträge zur Sprachwissenschaft.

Rieken, Elisabeth. 2005. Neues zum Ursprung der anatolischen $i$-Mutation. Historische Sprachforschung 118: 48-74.

Sasseville, David. 2018. New evidence for the PIE common gender suffix *-eh ${ }_{2}$ in Anatolian: Luwian - ašša- (c.) and Lycian B -asa- (c.). In 100 Jahre Entzifferung des Hethitischen. Morphosyntaktische Kategorien in Sprachgeschichte und Forschung, eds. Elisabeth Rieken, Ulrich Geupel, \& Theresa Maria Roth, 303-18. Wiesbaden: Reichert. 
Schaffner, Stefan. 1997. Der altfriesische Rechtsterminus bas(a)feng. Münchener Studien zur Sprachwissenschaft 57: 97-114.

Schaffner, Stefan. 2001. Das Vernersche Gesetz und der innerparadigmatische grammatische Wechsel des Urgermanischen im Nominalbereich. Innsbruck: Innsbrucker Beiträge zur Sprachwissenschaft.

Schindler, Jochem. 1980. Zur Herkunft der altindischen cvi-Bildungen. In Lautgeschichte und Etymologie, eds. Manfred Mayrhofer, Martin Peters, \& Oskar E. Pfeiffer, 386-93. Wiesbaden: Reichert.

Schumacher, Stefan. 2004. Die keltischen Primärverben. Ein vergleichendes, etymologisches und morphologisches Lexikon. Innsbruck: Innsbrucker Beiträge zur Sprachwissenschaft.

Solmsen, Felix. 19o9. Beiträge zur griechischen Wortforschung. Erster Teil. Strassburg: Trübner.

Steer, Thomas. 2014. Von der Hysterokinese zur Amphikinese: Akzentgebundener Ablaut bei der Substantivierung athematischer Adjektive. In Das Nomen im Indogermanischen. Morphologie, Substantiv versus Adjektiv, Kollektivum, eds. Norbert Oettinger \& Thomas Steer, 397-412. Wiesbaden: Reichert.

Steer, Thomas. 2015. Amphikinese und Amphigenese. Morphologische und phonologische Untersuchungen zur Genese amphikinetischer Sekundärbildungen und zur internen Derivation im Indogermanischen. Wiesbaden: Reichert.

Valera, Salvador. 2015. Conversion. In Word-formation, An international handbook of the languages of Europe. Vol. 1, eds. Peter O. Müller, Ingeborg Ohnheiser, Susan Olsen, \& Franz Rainer, 322-39. Berlin \& New York: Mouton de Gruyter.

Vine, Brent. 20o6. An alleged case of "inflectional contamination": on the $i$-stem inflection of Latin civis. Incontri linguistici 29: 139-58.

Vine, Brent. 2009. A yearly problem. In East and west: Papers in Indo-European studies, eds. Kazuhiko Yoshida \& Brent Vine, 205-24. Bremen: Hempen.

Wackernagel, Jacob. 1920-24. Vorlesungen über Syntax mit besonderer Berücksichtigung von Griechisch, Lateinisch und Deutsch. 2 vols. Basel: Birkhäuser.

Walde, Alois, \& Johann Baptist Hofmann. 1938-54. Lateinisches etymologisches Wörterbuch. 2 vols. Heidelberg: Winter.

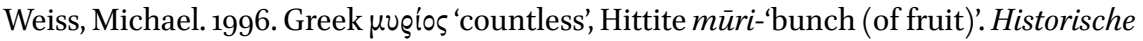
Sprachforschung 109: 199-214.

Weiss, Michael. 2010. Language and ritual in Sabellic Italy. The ritual complex of the third and fourth Tabulae Iguvinae. Leiden: Brill.

Weiss, Michael. 2013. Interesting $i$-stems in Irish. In Multi Nominis Grammaticus. Studies in classical and Indo-European linguistics in honor of Alan J. Nussbaum on the occasion of his sixty-fifth birthday, eds. Adam I. Cooper, Jeremy Rau, \& Michael Weiss, 340-56. Ann Arbor \& New York: Beech Stave.

Weiss, Michael. 2020. Outline of the historical and comparative grammar of Latin. Second edition. Ann Arbor \& New York: Beech Stave. 
West, Martin L. 1998. Homeri Ilias. Recensuit / Testimonia congessit Martin L. West. Volumen prius rhapsodias I-XII continens. Stuttgart: Teubner.

Widmer, Paul. 2004. Das Korn des weiten Feldes. Interne Derivation, Derivationskette und Flexionsklassenhierarchie: Aspekte der nominalen Wortbildung im Urindogermanischen. Innsbruck: Innsbrucker Beiträge zur Sprachwissenschaft.

Zair, Nicholas. 2012. The reflexes of the Proto-Indo-European laryngeals in Celtic. Leiden: Brill. 